CEREM O N IES

A.T THE

Saying of the Gorner Stone

OF THE

AMERICAN MUSEUM

OF

NATURAL HISTORY. 


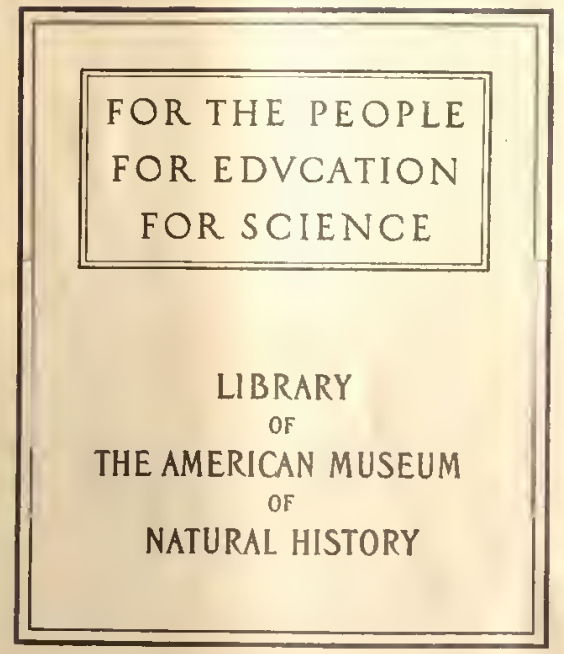




CEREMONIES

AT THE

$5.07(74.71)$

Saying of the Sorner Stone

OF THE

\section{AMERICAN MUSEUM}

OF

NATURAL HISTORY,

TUNE $24,1874$. 


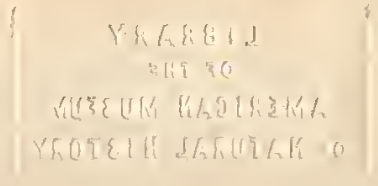

$23.906+7$ fr. 21 


\section{CEREMONIES.}

PRAYER BY Rev. S. H. TYNG, D. D.

O Lond, our God! blessed be Thy great and glorious name, which is exalted above all blessing and praise! Thou, even Thou, art Lord alone. Thou hast made heaven, the heaven of heavens, with all their host, - the earth, and all that is therein, - the seas, and all that therein is, and Thou preservest them all. The host of heaven worshipeth Thee!

Whither shall we go from Thy Spirit, and whither shall we flec from Thy presence? If we ascend into hearen, Thou art there; if we make our hed in hell, behold Thon art there. If we take the wings of the morning, and dwell in the uttermost parts of the sea, even there shall Thy hand lead as, and Thy right hand sliall hold us. Such knowledge is too wonderful for us; it is high, we cannot attain unto it.

O Lord, our Lord! liow exccllent is Thy name in all the earth! who hath set Thy glory above the leavens. When we consider the heavens, tho work of Thy hands; the moon and the stars which Thou hast ordained-what is man that Thou art mindful of him, or the son of man that Thou visitest him? Thou hast made him a little lower thas the angcls; Thou hast crowned him with glory and honour. Thou madest him to have dominion over the works of Thy hands. Thou hast put all things under his feet.

o Lord, how manifold are Thy works! in wisdom hast Thou made them all. The earth is full of Thy riches. This great and wide sea also, wherein are creatures innumcrable, both small and great; these all wait upon Thee, and Thou givest them their meat in due season. Thou makest the grass to grow upon the mountains, and herbs for the service of man. Before The the mountains break forth in singing, aud all the trees of the field shall clap their hands, from the cedar that dwelleth in Lehanon, even unto the hyssop which springeth out of the wall. Thon hast commanded us to commemorate Thy wisdon and Thy power; to teach unto those who come after us the glory of Thy works-as wonderful in the least of the beings that breathes in Thy mercy, as in the mightiest that displays and magnifies Thy

- power. Thou hast manifested Thyself and Thy wisdom, as truly in the lilies of the field as they grow as in the leviathan, who is the king over all children of pride.

To honor Thee in all these works of Thy hand, would we erect the build. ing over the foundation of which we now ask Thy protection and Thy 
hlessing. May it perpetuate the rememhranee and the study of Thy wisdom and goodness, as all Thy works deelare them, and as the knowledge and thankfulness of men thus eombine to make them knowu. Great and marvellous are Thy works, Lord God Almighty! just and trne are all Thy ways, thou King of Saints !

We would humbly, gratefully praise Thee, in all the works of Thy hands and in the wonders of Thy pardoning love to the clildren of men. May Thy graeious blessing rest upon our heloved country-upon the land whieh Thou gavest us to inhabit-upon the President of these United Statesupon all whom thou hast estahlished in authority among this people. Prosper, we beseech Thee, all our institntions and efforts for the advancement of luman learuing. Give habits of righteonsness and trutl: to all our people. Uphold and edify every plan for the advancement of puhlie and private virtue, and every effort to reform and rescue the onteast and the negleeted among our people.

And above all give peaee to our natiou-prosperity to Tlyy Gospel of Salvation-and the maintenanee of Thine own supreme authority, in the name and person of our Lord and Saviour, Jesus Christ. In wlose words we wonld gratefuly say,-

Our Father, who art in heaven, Hallowed be Thy uano. Thy kingdom eome. Thy will be done on earth, as it is done in heaven. Give us this day, our daily bread. And forgive ns our trespassen, as we forgive those who trespass against us. Lead us not into temptation, hut deliver us from evil. For thine is the kingdom, and the power aud the glory, forever and ever. AMEN.

\section{ADDRESS by Roberte L. Stuart, Escl., President of the Museum, in behalf of the T'motecs.}

WE have assembled on this oecrsion by the invitation of the Trustees of the American Museum of Natural Iistory, to kay the Comer Stone of the generous edifice which, by the wise libcrality of the state of New York, has been provided for the perpetual use of the Museum, and, in the appropriate presence of the Chief Magistrates of the City, the State, and the Nation, to dediente the structure to the publie serviee for which it is designed.

In this vicw it mily not be unbeconing for the Trustees briefly to rclate the course of events which have broiglit this undertaking to its present advaneement, and to declare the purposes which hare aetuated them in the efforts they have made to establish, on a permanent foun. 
dation, a Museun which, as they hope, will be worthy of recognition as a National Institution.

It had long been a subject of regret to mauy citizens interested in the cause of education and eulture, that this great city, the most prominent seat of Ameriean eivilization, slould remain entirely destitute of any adequate means for the study of Natural History, while all the other principal branches of science and knowledge found within it their professors and their colleges, whieh invited students from all parts of the laud, and furnished them with suitable facilities for acquiring tho special edncation whieh they sought. It was also considered that a department of knowledgc which has in recent years assumed so large a share of attention and so nurked a place in every scheme of Liberal Education, should have in this city a grand collection of specimeus, free to the inspeetion of its own citizcns as a source of public aunusement, and open to the use of the teachers and scholars of its public and private schools as a ueaus of general instruetion.

It was for these purposes that the Legislature of the State of New York, by an Act pissed on the 6th of April, 1869, ereated the Trustees and their successors a body eorporate by the name of "The American Museum of Natnral History," to be located in the City of New York, for the purpose of establishing and maintaining in said city a Museum and Library of Natural History; of encouraging and developing the stuly of Natural Science; of advaneing the general knowledge of kindred subjects, and to that end of fumishing popular instruction and reeration. Under this Charter the Trustecs immediately organized, and lave, during the five years which have since elapsed, devoted 110 inconsiderable amonut of time and thought, as well as of money, to earrying into praetical operation its nseful provisions. Having by their own contributions, and those of many public-spirited citizens who evinced a substantial interest in the project, obtained the necessary means, they purchased the extensive colleetion of Mammals, Birds, Fishes, etc. belonging to the late Prince Maximilian of Nenwicd, the Filliott collection of Birds, besides a large part of the celebrited Verreanx and other eolleetions of speeimens of Natural History, and thus found themselves in possession of a snitable uueleus for a emmplete collection, but without any proper building or place of deposit, where the specimens might be at the same time safely preservel and made arailable for the popular use and enjoyuent. $\Delta t$ 
this stage in their entcrprise, the 'Trustees, bcing thus able to furnish a substantial guarantee of their earnest determination to accomplish what they had taken in hand, turned in their hour of need to the Commissioners of the Ceutral Park, who by their uniform devotion to the trusts committed to their carc had done so much to advance the welfare and the pleasure of their fellow citizens, and proposed to deposit their collections, for sate keeping and exhibition, within the limits of the Park itself, and add the Mnseum to the already great attractions of this favorite place of resort. The Trustees were met by the Commissioners with the most enlightened and liberal sympathy, and the proposition was accepted by them with the declaration on the part of the Commissioners, which the event has justified, that the proposed plau of co.operation, which insured and combined in the cnterprise the interests and meaus of the private citizen with those of the public, would probably be made an cxamplc and incentive for miting the energies of those interested in other branches of Science and Art in similar undertakings.

Thus by the favor of the Park Commissioners, at the close of the $\mathrm{ycal}^{\circ}$ in which the Charter of the Museum was granted, its valuable trcissures first acquired were deposited and arranged under the protection of the People, iu the Arsenal bnilding in the Park, accordiug to writteu articles of agreement, by which, although remaining the inviolable property of this privale corporation, they were secured and prescrved for the free instruction and enjoymeut of all who chose to visit theus.

From that time to the present the Trustces acknowledge with gratitude the uutiring sympathy and co-operation of the Commissioners aud their successors in the Department of Public Parks, by meaus of which the public has been euabled to enjoy the full bencfit of all which the Trustees have succeeded iu acquiring. The fact that the rooms which were allotted to the use of the Museum have been visited daily by thousands of all ages and clnsses, and that the public interest in its success has steadily and rapidly increased, is a satisfaclory proof of the wisdom of that joint arrangement.

It very soon however became evitent lyy the rapid growth of the Museum, and the constant additions which accrued to its collections, that the temporary accommodations which were the best that the Park Commissioncrs bave thus far been able to afford, were altogether 
inadequate for the purpose to which they were devoted, and accordingly the Legislature, in response to the Petition of a large number of infuential Citizens interested in the cause, by an Act in 1871 relative to the Department of Publie Parks, authorized the Commissioners to erect upon Manhattan Square, a suitable fire-proof building for the purpose of establishing and maintaining the Museum therein, nnder rules and regulations to be prescribed from time to time by the Commissioners, and in the same connection and by the same act the like provision was made for a similar building for the use of "The Metropolitan Museum of $\mathrm{Art}$," the foundations of which are already being prepared by the Commissioners on the opposite side of the Park.

By this double act of munificence on the part of the people of the State, the City of New York las been endowed with two institutions of education and ornament which, thouglı now in their infancy, will at no distant day be recognized as of great and permanent public advantage, and whatever jealousy may justly pertain to appropriations of public money to private uses can in no way apply to this Museum of Natural History. Its Trustecs have no personal objects to serve-no private ends to aceomplisl. They can gain nothing for themselves from this or from any future endowruents which the wise policy of the Legislature may furnish to carry out and perfect this undertaking. Their aims will be all attained, if the people of the City shall justly appreciate its value, and if its accumulating treasures shall be freely and wisely used by all who seek them.

Weshould not do entire justice to this occasion if we failed to record the gratitude of the Trustees and the community, to one eminent citizen whose memory is still fresh with us, and will long be kept green by the perennial growth of the charities which he founded and sus. tained.

To Jorr DAFin Wotfs, the first President of this Museum, we are much indebted for its successful establishment. He entered with zeal into the project of its creation, believing that it would prove an honor to his native City, and an importaut means of education to its citizens and their children, and dying at a ripe old age, he commended its care and support to those who have the means and the disposition to do something for the public welfire.

In recalling, with pride, the progress that has already been made towards the realization of their plans, the Trustees desire to place on 
record their high appreciation of the services of Professor A L LBert S. BICKMoRE, whose zealous devotion to the interests of the Institution, and untiring industry in carrying out the wishes of the Executire Committee, have done mueh to advance the prosperity of the Musenm.

We lay here to-day the Corner Stone of an edifiee whieh shall be dedicated forever to the study and the culture of Natural History. These massive foundations already securely laid gire promise of the most solid permanence in the superstructure. The wise forethought of the Park Commission, in reserving for the future use of the Museum the remainder of Manhattan Square, las provided amply for its eon. tinued growth.

The presence on this occasion of the President of the United States, who has kindly consented to assist us in these ceremonies, assures us of that public interest which is necessary to sustain the undertaking.

The cheering words of the Governor will doubtless lend the coun. tenance of the State to support this institution whieh has been fouuded by its bounty, and finally, the Trustees, in pledging onee more their own efforts for its success, would bespeak for it that popular favor without which it must surely languish and decay.

\section{The Hon. H. G. Stembins, President of the Depart- ment of Parks, spoke as follows:}

When the arrangements for the eelebration of the ceremony which has brought us here to-day were made, the duty was assigned to the Hon. SALFM H. WALES, then President of the Park Commission, to represent the Department on this important occasion. He has since then resigned his officc as Comnissioner and gone abroad. It devolres upon me to perform the duty which he had expected to fulfill.

As he had prepared an Address for this occasion I shall takc the liberty of reading it, and of expressing iny sincere regret that he is not here to carry out the prograume we had agreed upon. NIr. WALEs,
in that case, would have said-

The Legislature of the State of New York, at its session of 1864, placed Manhattan Square, a piece of property belonging to the City; situate between 7 th and 81 st streets and 8 th and 9 th avenues, consisting of alout 19 acres, under the control and management of the 
Commissioners of the Central Park; and it was made the duty of the Board to enclose, lay out, grade, regulate, drain and improve, the same; and by subscquent enactment in 1868 the Board was authorized to erect, establish, conduct and maiutain on the Central Park, a Meteorological and Astronomical Observatory, a Museum of Natural History and a Gallery of Art, and the buildings therefor, and to accept gifts, devises and bequests upon suitable conditions.

Although the Board of Commissioners was thus early clothed with ample authority to establish within the Park a variety of museums that would afford the usans of popular cultivation and inmocent recreation, yet they have folt that, to insure the proper management of such institutiona, it would be better to leave them to the care of private associations than for the Board to expend public money in the purchase of specimens of Natural History or works of Art; and in giving encouragement to private organizations, the Board made known at its outset that not only the object of the Association must be approved, but its sound organization and undoubted ability to command the means necessary to accomplish its purposes according to a high standard of excellence, must be first demoustrated. It was, therefore, with feelings of great satisfaction, that the Commissioners, on the 30 th of Deccmber, 1868 , received a letter from a number of well-known citizens, inquiring if the Board was disposed to provide for the reception aud development of a Museum of Natural History.

In reply to this letter the Comptroller of the Park wrote, that "the Conmissioners will very gladly receive the Collection to which you allude, and will use their best exertions toward the establishment of a Museum of Natural History of an extent and excellence in all its departments that will be creditable to the City; and in their efforts toward the development of such an institution, the Commissioncrs of the Park will higlily esteem your valuable co-operation."

In pursuance of the anthority vested in the Commissioners of the Contral Park, and in accordance with suitable mles and rcgulations, the building known as the Arscnal, situate on the cast side of the Park, was carefully fitted up and arranged for the temporary reception anil proper cxhibition of a rare and most valuable collcction of objects of Natural History, which had been gathered under the patronage of the American Muscum of Natural History - a society composed of some of our most public-spirited citizens, and offering every guarantee 
of the successful accomplishment of the oljeet for which they were incorporated.

Such has been the zeal and earnestness displayed by this Society in the prosccution of its work, that the space already allotted in the Arsenal buildiug is now wholly inadequate for the proper display of thcir precious Collections, and the Departinent of Public Parks has determined to construct a much more extensive cdifice, which in its general design and purpose should equal the largest musenms of thic Old World. We are here to-day to lay the Corner Stone of such an edifiee, and as the representative on this occasion of the Department of Public Parks, I take great plcasmle in assuring the Trustees and the friends of the Society of the great interest felt by the Commissioners in the success of this worthy enterprise. To the stranger who comes here to-day these rugged foundation walls and these rough surroundings are not well caleulated to makc a pleasant impression; but to us who have watched the rapid growth northward of this city, and who were familiar with the barren and rocky ground npon which the Central Park has been created, it requires but little strain upon the imagination to couceive of the speedy oceupation of all these vacant lots by substautial dwellings, and to picture to ourselves the spot upon which we now stand, known as Manhattan Square, as cuvered by the pro. posed Museum of Natural History, costing, cre its final completion, net less than $\$ 6,000,000$, and embraeing a collection of objects of scientific interest seeond to none otlrer iu the world. As a people we are sometimes accused of cxcessive practical and money-making characteristics; and it cannot be denicd that in ail the varied arts and appliances wluch minister to the material progress of mankind we have shown rcmarkable encrgy. The Patent Office at Waslington is a stately monument that bears witness to the palient genius which has wronght out the wouderful inventions now so largely employed in all the busy affairs of the country; and while it is true that mcehanical and agricultural fairs and exhibitions have extended their good influences throughout every State and connty in the land, it must be acknowledged that the same attention has not been given to the collection of objects of Natural Ilistory, of which our country has almost an infinite varietiv.

With the acquisition of wealth and the introduction of ease and luxury in the homes of the rich, there comes most naturally the 


\section{1}

enlarged and more noble thought of doing something not only to amuse, but also to instruct the people.

The subject of muserums is beginning to assume new importance in the estimation of the pcople.

Hitherto, small and comparatively worthless collections have been gathered by private cnterprise, and employed chiefly for purposes of speculation. That which is temporary and speculative must now give way to something more cnduring and instructive, and it seems to me that our thanks are especially due to the Society of Natural History for acting the part of pioncers in this great field of science, and for the zeal which they have shown in the prosecution of the work. So far as the Departunent which I now represent is concerned, I do not besitate to promise all the assistance it can lawfully render. We encourage it as not only an object of public interest which shall serve to attract hitherward strangers from all parts of the land, bnt also as a means of intellectnal pleasure, profit and relief to our over-burdened people, and as affording a school whcre the children of the rich and poor alike can come to study the wonders of nature which are here to be gathered togcther, and fiecly exposed for the common benefit of all. It is believed that the museums on the Park will become valuable auxiliaries of that great free public edncational system which is already the pridc of our city, as well as the source of useful practical information to agriculturists, mcrchante and manufacturers throughout the land. In this country we popnlarize knowledge, and give to science a holiday air, and instead of putting our collections, as some have proposed, "into cold catacombs of science, and long gloomy galleries in which nature is classified, ticketed, stuffed and covered with dust in a manner well adapted to create weariness rather than to attract people to the stidy of naturnl objects," it is our purpose to provide such structurcs as shall furnish agreeable entertainment to the general visitor, while at the same time offering valuable aid to common school education.

With the hearty co-operation of the Natural History Society, sus. tained by the genins of Olmsted and the architectural skill of Vaux, and certain of the sympathy of an enlightened people, thc Department of Public Parks looks confidently forward to the successful completion of the magnificent schcme, the commencement of which may now be prononnced as fully inaugurated. 
What Mr. W ALEs has said, and I have just read, will conrey a full conception of the purposes of the structure which is formally begun to-day. I feel it to be a great honor to assist in the commencement of a work which will, I trust, be luastened to conupletion before the Centennial of our Independence; hcre to stand as a magnificent memorial of what our City has been able to accomplish under free institutions, and to become a part of the material resources that will ultimately go to the crcation, around this Park, of the lome of a National University.

What nobler exhibitions conld be griven of the crowning achievements of this municipality than those which this Mnseum and its vister institution, the Art Gallery, will afford? 'l'his peerless plunsure ground for the people, which will prondly boast of these twin jewrels as its legitimate offspring, will contain within itself in miniature the records of the progress of the country. Its wiluerness spots remain as souveuirs of what the wholc trict was a few short years ago-when a prophetic Samuel B. RugGlws saw the possibilities that are now accomplished faets. Its artistic decorations and its Muscums of Art and Natural History will show the hest pesults of a high civilization, and of a liberality directed by the wisest forethought and the most
cultured taste.

\section{ADDRESS OF GOVERNOR DIX.}

\section{Ladiks AND GENTLEMEN :}

I did not come here with the expectation of addressing you You may fud it difficult to believe what I say when you see me pres. ent, and my name in the published order of exercises as a speaker. But, I can assure you, that I had no intimation from auy quarter that such a service was expected of me, and no knowledge that such a notice had bcen given to the public nntil I sat the programuse a day or two ago, by pure accident. I only say this to exonerate my. sclf from the possible imputation of having made au engagement and failed to perform it; and to tender to you an apology which I an? sure you will, under the circumstances, derm a valid one, for respond. ing in the most summary manner to your kindness and conrtesy.

I am very much gratified to lie with you on an uccasion of so much interest. It is plcasant to stand anid this brilliant asscmblage of beanty and fashion, and of those solid qualities, by which the welfare and prosperity of eities and commmnities are wrought out. It is pleas. 
ant to see a great metropolitan city like this, casting aside for the moment the babiliments of its industry, to lay the foundation of a Museum in which the dead past is to be linked to the living present; to be followed as we trust, at no distant day, by a repository of art, where the ages that have gone by may be kept in our remembrance, by gathering together the memorials of their achievements; where the stately marcli of Eimpires may be chronicled to some extent, by the exhibition of what they have done for social embellishment, and where the gorgeousness and profusion of Nature may be emulated by the creative genius of Art.

I know no locality so suitable as this, for such a Museum of artistic treasure; no locality in which Art has already done so much for $\mathrm{Na}$ ture. Nost of us remember when, but a few years ago, this whole district, which now forms the Central Park, was an unsightly and shapely mass- " mudis indigestaque moles." Now it is a very miracle of rural beauty, where the most unpromising and stubborn natural feature has been made to blend and harmonize with the general aspect of order and grace.

But, ladies and gentlemen, I am forgetting that I only arose to apologise to you for sitting down again; and if I go on, you may impute to me the common frailty which Horace ascribes to singers-
that they can never be induced to sing when they are asked, and never stop when nobody wants to hear them. But I cannot sit down without saying, it is appropriate that the foundation of this Cosmopol. itan Museum should be laid by the foremost man of our time, who in the field did so much by his calm, unconquerable and unconscious valor, to save the life of the nation, and who in the Cabinet stands forth as its fearless champion, to maintain its honor and its plighted faith.

\section{ADDRESS OF PROF. JOSEPH HENRY.}

\section{Mr. President, Ladies and Gentlemen:}

My address will bave onc element which I doubt not will elicit your approbation. I was requested to limit it to ten minutes, and therefore it will of necessity have the merit especially appreciated on 
a warm day, that of shortness. Being thus instructed as to time, I trust I shall be excused if I do not as fully develop as could be wished the several propositions which I intend to present in connection with the interesting occasion on which we are asscmbled. The first of these propositions is that modern civilization tends to congregate the population of countries into large cities, that cities tend to increase more rapidly than the general population. 'Tlsese effects may be referred to two causes, first, the education of the working classes, and secondly, to the introduction of labor-saving machines. These causes are notably illustrated in New England, where the masses are more highly cducated than in any other part of the world. No sooner does the young New-Englander approach manhood, alter having enjoyed the benefits of a common school education, thau he abandons the plow and the spade and hurries to the city or the manuficturing village to obtain more intcllectual and less toilsome employment. 'I'be vacuum which is thus produced is, however, more than filled by the invention, it may be by the same individual, of patent machines actuated by steam or horse-power, which will do, in many cases, a hundred fold more work in a given time than the man himself conld accomplish. Another proposition to which I would call your attcntion is that cities in proportion to their extent and rapidity of growth engender babits of thought and of action of a character the reverse of progress, and which, if unrestrained, wonld tend to disintegrate socicty and resolve it into its primitive barbarous elements; that these principles are eminently applicable in New York, which, inchuding the whole population at the mouth of the Hudson, is now a vast city, and is destined to become, I say it withont hesitation, the largest city in the world: no other city having so large a country tributary to it in the richest productions of the soil and mine, and no other city so favorably situated in regard to geography and topography to secure these tributaries perpetually to itself. There are in fact but two ontlets for water communication from the immense region of the basin of the Mississipui, namely, that along the river itself into the Gulf of Mexico ncar NewOrleans and that along the great lakes and the Hudson, terminating at New-York in the Atlantic Ocean.

It is therefore of the first importance that those who possess the intelligence, the influence, and the power, who from the experience of the past are impressed with the tendencics as to the future, should 
endeavor to provide all the means possible to avert evils similar to those with which this city has been afflicted, and which tend to aftict it in a still greater degree in the future.

Among these means I would of course place in the first rank a liberal support of the Christian minister and the Christian missionary, but the labors of these may be greatly aided by whatever tends to neutralize the intensified selfishness engendered by the struggle in a large city for supremacy, and the unfavorable effort of extreme exclu sion from intercourse with nature, and above all, the ready indulgence of degrading passions. Tlis is espeeially the province of museums of art and nature. They not only offer a substitute for immoral gratifieations by supplying intellectual plensures, but may also be rendered sources of moral and everr religious instruetion. The establishment, the beginning of which we are about to inaugurate is, in accordance with the views we have presented, worthy of the enterprise and intelligence of those who conceived and who have thus far developed it. It is to be a temple of nature in which the produetions of the inorganie and organie world, together with the remnants of the past ages of the human fanily are to be collected, classified, and properly exhibited. It is to be rendered an attraetive exhibition which shall arrest the attention of the most unobscrving of those who, having been confined all their lives to the city, have eome to eonsider cdifices of briek and of stone as the most prominent objects of the physical world.

We have learned from the interesting address of the President of the Mnseum, that already large collections of specimens in natural history and ethnology have been seeured. But such a collection, however well arranged and intcrestingly displayed, is still wanting in an essential element of higher usefulness. I allude to the spiritual part of its constitntion, to the controlling, intelleetual, and moral soul which shall direet its operations and instruct the multitudes who may flock to the exilibition for amusement or the gratification of mere curiosity, in at eraving for novelties. How incomparably greater would the importanee of this museum be were there connected with it a professor, who at stated periods of the year would give courses of free lectures on the objeets whieh it eontains, who would expound the laws of the phenomena of nature, who would point out the operations of that mysterious prineiple ealled life, who would disconrse upon the changes the world has undergone during geological periods, and who would 
reconstruct the history of man in primitive times from the rennants of his previous existence which have heen gatherce in this institution.

For example, what an effect would be produced on thousands of the inhabitants of this vast city if it were announced that an $\Lambda$ gassiz, filled with enthusiastic sympathy with his subject and his audienee, and capable of mingling moral considerations with scientifie principles, of directing attention from nature to nature's God, of not only en: lightening the heads, but of warming the hearts of lis andience, wive to give free courses of instruction.

Such an announcement would be hailed with intense interest by thousands, and the amphitheater of the museum would be crowded to overflowing with receptive and almiriug auditors. I need only sug. gest such an arrangement to find, I doubt not, an appreciation of its importance in every one of my hearers, and the hope felt or expressed that the directors of this estabiishment will endearor to provide an endowment for the support of such a feature of the inusenm. But I have not yet done. The development of the institution would not yet be complete were it even furnished with all the appliances I lave mentioned. There is still another duty which this city owes to itself and to the civilized world; I allude to an endowmeut for the support of a college of discoverers, of a series of inen capable not ouly of ex. prounding established truths but of interrogating nature and of discov. ering new facts, new phenomena, aud new principles. The blindness of the public to the value of abstract science and to the importance of endowments for its advancement is truly remarkable. No country in the world is so much indebted for its progress in power aud intelligence to science than ours, and yet no conntry does so little to encourage or advance it. Nearly all that is done in this line, is by professors in col. leges, badly paid, and gcnerally overworked. It is not every one, however well educated, that is capable of becoming a first-class scien. tist; like the poet, the discoverer is born, not made, mul when one of this elass has been found he should be cherished, liberally provided with the means of subsistcuce, fully supplied with all the implemcuts of investigation, and his life consecrated to the ligh and holy office of penetrating the mysteries of nature. Wliat has been achicved in the knowledge of the forces and operations of nature and the use to which this knowledge, has been applied in controlling and directing thesc forces to useful purposes, constitutes the highest claim to glory of our 
race. Yet it is a melancholy fact that, notwithstanding the reputation for wealth and intelligence possessed by our people, for the only institution intended espeeially for the advaneement of scienee in this country we are indebted to a foreigner, James Smithson, and that a rery large portion of the income of this has wrongfully been devoted to the erection of a costly edifice and the embellishment of grounds, and expenditures on other loeal objects unnecessary for the realization of the intentions of the founder. I am happy, however, to say that after 25 years of incessant efforts in one line by the directors, Congress has at length been incluced to indicate au intention of redressing the evil, and enabling the establishment to devote its whole energies to the advance of science, the evident design of the testator. New York at present is the wealthicst, most powerful, and influential eity of the Union, and is destined in the future to be more so. But do not be offended with me if I say in perfect eandor and with the desire of doing good, that it has done less than any other eity, in proportion to its means, to alvance seience. More than 75 years ago, Boston established the American Acadciny of Arts and Seiences, which, annually ever since, las given to the world the result of original labors in the way of new discoverics.

I'hiladelphia before the revolution, under the auspiees of Franklin, established the Ameriean Philosoplical Society, which has still a vigorous existence, and continues to annually send its transactions to foreign societies in exchange for theirs. New-York, also, more than 50 years ago, commenced to establish a Philosophical Society, which expired, however, in giving birth to a single memoir by De Witt Clinton on the inportunce and value of such an establishment. It is also true that anong so many people there have becn some who have been zealously devoted to seience, and have done honor to it and the world, such as a Redficld (I speat only of the dear), who established the laws of storms, and a 'lorrey, who devoted an unobtrusive, indus. trious and productive life, to the advance of ehemistry, mineralogy, and botany. Boast not of wealth, nor of refinement, while original powers of intellect, the choicest gift of heaven to man, is at a discount among your. I appcal to the millionaires of this eity, if any one of them is desirous of pcrpetuating his name and of living in the memory of mankind long after he las departed this life, to endow, eonnected with the Park Mnseum, a Coliege of Discoveries, with the additional 
means of printing and disseminating over the world the results of its labors. I refer him to the effects which are being produced in regard to the name of James Smithson, a scion of one of the noble houses of England, who rightfully anticipated that through the endownent of his institution his name would live in the history of mankind when the titles of his proud ancestors were cxtinct or forgottcn. Erery year a publication is issued from this institution, filled with an account of new discoverics made under its auspices, which is distribnted to more than 2,000 foreign institutions. This publication, bcaring the aame of Smithsonian Contributions to Knowlcdgc, thus renders the name of the founder ubiquitous with continual repctitions, until now, it has become as familiar as a household word in crery part of the civilized world. What, in comparison to this, are local monuments, pyramids of fiut, statues of brass, or obelisks of marble? These are scen but by the few and are constantly subjected to the slow bint surc destrojer, time; while the other is everywhere present, and is as cnduring as civilization itself. The operations of the universo are unlimitcd, and in the great book of nature, man has scarcely read morc than the title-page or the preface. It was the saying of La Place, "What we know is nolhing; what we do not know is immense; indecd every advance of knowledge but enlarges the sphere of our ignornnce." How many problems of the highest interest arc pressing upon us even in the line of biology. What is vitality? Is it an mintelligent force of nature, like that of attraction, producing crystallizition, or an intelligent prin. ciple operating by the ordinary forces of nature, prodncing results indicating desigu and consequent intcntion? Can deal matter be made alive under the influcnce of certain conditions withont propagation from parents - this is a question which cannot he solved a priori, and must wait the decision of refined experiments. It las been reduced to a fact that either every breath of air we inhale, that every portion of the cartli's atmosphcrc, is teeming with the germs of living organisms, or that dead matter may spring into life in accord. ance with the process of what is callcd spontancous gencration. In science every advance in the way of discovery gives us a higher point of view for making cxeursions into the regions of the unknown, and the man of science, however extended his vision, however nultiplied his resources, can never want for worlds to conquer.

God has created man in his own intclloctual image, and gracionsly 
permitted him to study His modes of operation, and rewards his industry in this line by giving him powers and instruments which affect in the highest degree his material welfarc. It was the recognition of the importance of original science that rendered France a few years ago the center of civilization of the world. The celebrated Museum, called the Garden of Plants, was not a museum, as it were, of dead specimens for the gratification of ordinary curiosity, but the theatre of the labors of a Cuvier, a St. Hilaire, and of the many distinguished men which have rendered the scientific annals of that country Immortal.

Germany owes her ascendency at the present day not only to thc general education of her people, but to the mcans which she has provided for the discovery of new truths.

England is becoming awakened to the importance of the same object, and a portion of the immense income of her universities is now devoted to the support of original investigators.

With the hope that you will excuse the plainness of some of $\mathrm{my}$ remarks, and attribute them to my ardor for the advancement of knowledge, and a desire to stimulate the inhabitants of this city to efforts in the line in which I am most interestcd, rather than to a tendency to indulge in depreciation or cynical criticism, I must close my address and throw myself upon your indulgence for having involuntarily, as it were, exceeded the limit of my time.

At the conclusion of Professor Hexry's address, the Superintendent of the Museum read thc following list of articles in the box to be placed in the corner stone:

1. Reports and Circulars of the Museum.

2. Reports of the Dep't of Public Parks for 1570,1871 and 1872.

3. Janual of the State Legislature.

4. Congressional Directory. 
5. Daily Papers—the "New York Tribune," "Times," "World," "Herald," "Sun," "Evening Post," "Mail," "Express," "Commercial Advertiser," "Journal of Commerce," "StaatsZeitung," and the "Courier de Etats-Unis," "Appleton's Journal," "Harper's Weekly Illustrated Paper," and "Frank Leslie's Weekly Illustrated Paper."

6. One Dollar and fractional parts in currency.

One Dollar and fractional parts in coin.

The Treasurer deposited the Box in the Conser STose, which was then laid by

\section{Mis Excellexcy}

GEN'E, U. S. GRANT, President of tile Uxithi States.

The exercises closed with a Benediction pronounced by the Rev. Henry C. Potter, D. D. 


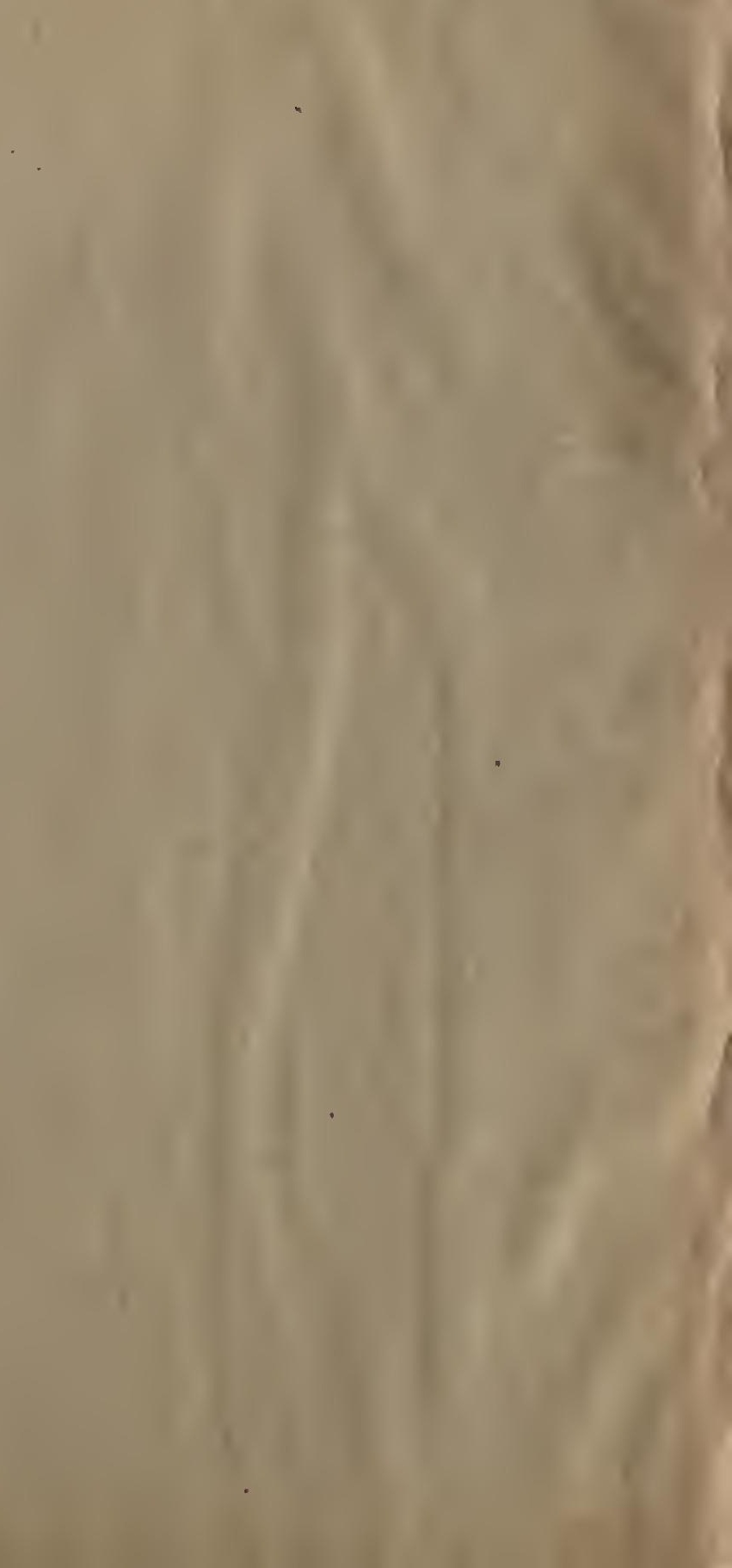

$y$
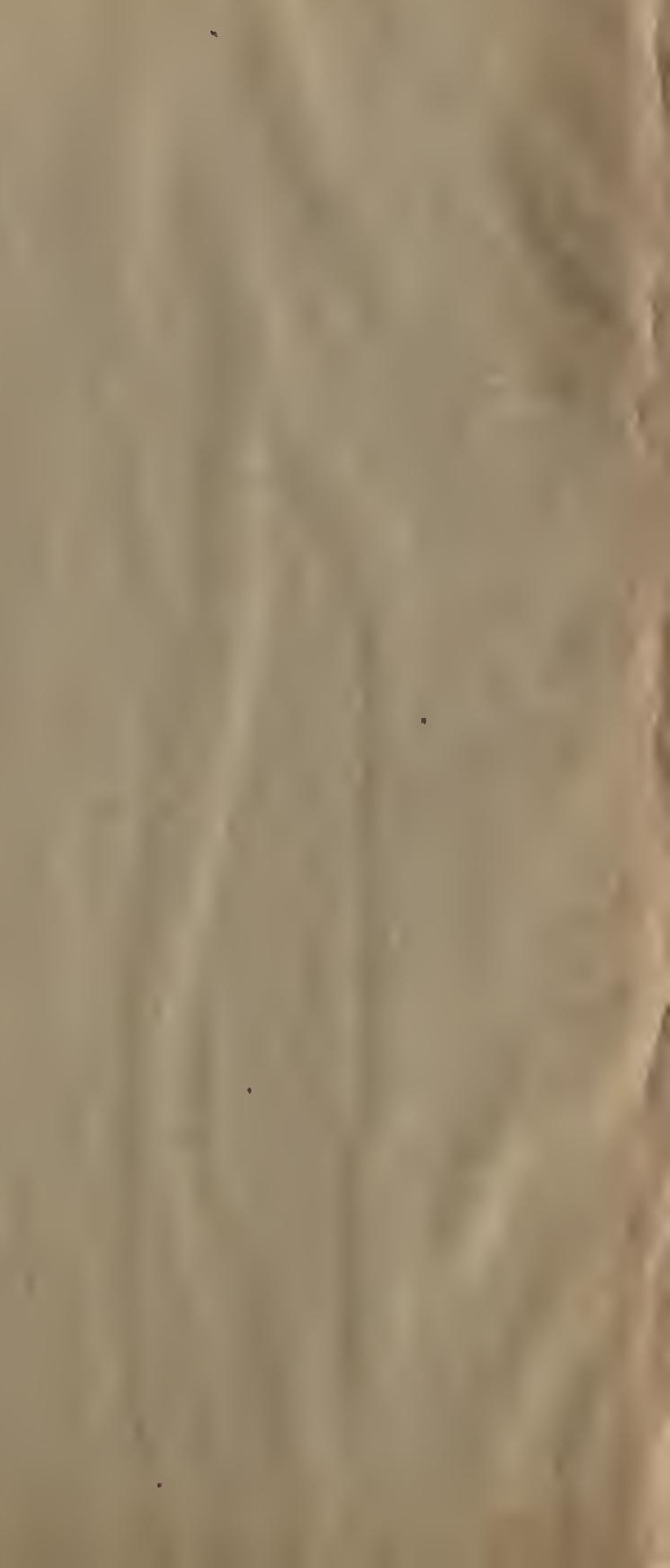

, 

